\title{
MODEL FOR ENERGY-EFFICIENCY AUDIT AND MONITORING OF THE COAL PROCESSING SYSTEMS IN THE FOSSIL-FUEL POWER PLANTS
}

\author{
OGNYAN DINOLOV ${ }^{1 *}$ \\ ${ }^{I}$ Dept. of Electric Power Engineering, Angel Kanchev University of Ruse, Studentska 8, \\ Ruse, 7017, Bulgaria
}

\begin{abstract}
Based on interpretation of existing developments, an aggregate model for energy audit and monitoring of the electric-energy efficiency in the coal processing systems in the fossil-fuel power plants is developed. The model takes into account the nominal power capacities of the available drives, by which the usability of the installed power capacity is considered and the interdependence between the power consumed and the relative consumption is avoided in determining the aggregate relative electric-power consumption. The model is justified by conducting an energy audit of a typical coal processing systems in operation. The results of this research can be a basis for the development of models of systems and systems for qualitatively new monitoring of the overall electric-energy efficiency in the fossil-fuel power plants.
\end{abstract}

Keywords: energy audit, electric-energy efficiency, monitoring, fossil-fuel power plants, energy-efficiency control, energy management, models for audit

\section{INTRODUCTION}

Conducted studies [1] indicate that, at present, the potential for improving the energy efficiency (EE) in steam power plants is high. The research in this area is particularly well represented in India [2], where the majority of electric power generation is provided by these plants.

The analysis of the developments in the field of the constructional and regime parameters of the steam generators, including their electric-drives systems, shows that, on the whole, the EE optimization is targeted at different directions as different available options are used. Results are achieved by reducing the excess air for pneumatic transport, lowering the temperature of the flue gases, a forced cooling of the water vapour [1], optimizing the construction of the heat exchangers [3] and of the hoppers for coal and coal powder [4], air slag cooling with increasing the steam-generators' efficiency factor with more than $0.5 \%$ [5], as well as by improving the performance of the turbo alternators which, according to some authors [6], are among the most ineffective elements of the steam power plants. Different systems for control of the current processes are also available [7, 8].

After the feed-pump systems, the fuel-preparation systems in the steam power plants are found to be one of the most powerful ones as, for a typical fossil-fuel power plant, their installed capacity averaged $15 \%$ of the total installed capacity of the other systems supplied at a middle voltage [9]. Given the topicality of the issue, a number of implemented optimization tasks and models for improving the EE of the considered objects are referred in literature. In [10], a modernization of three fossil-fuel power plants is described: replacing the existing pulverizes with those with higher productivity and with the ability to work with coal with a wider range of variation of the

\footnotetext{
* Corresponding author, email: odinolov@uni-ruse.bg

(C) 2016 Alma Mater Publishing House
} 
quality parameters; increasing the number of outgoing coal-powder conduits of the pulverizes, in order to reduce the hydraulic resistance caused in splitting the fuel flow; installation of additional hot-air fans to the pulverizes; modification of the burners resulting in better mixing of the coal powder in low loads of the steam generator; using two hoppers for supplying raw coal to one pulverized with a view to mix coal with different quality parameters. The modernization has led to reduction of the harmful emissions and the self-consumption of the steam generators. In another development [11], an improvement of the efficiency of such generator with $2 \ldots 3 \%$ is realized for a main plant in Russia just by optimization of the plant's coal processing systems.

Energy auditing of the coal processing systems in Bulgaria is regulated by a corresponding legislation [12]. In this regard, some case studies [13] are conducted and some generalized developments $[14,15,16]$ are proposed, the core of which is the methodology [15] for investigation and evaluation of the EE of the aggregate systems for preliminary transport and processing of coal. Similar generalized developments are not proposed by other authors. Disadvantages of the methodology are the lack of possibilities for evaluating the EE of a group of pulverizes operating in parallel, and its unsubstantiated performance and applicability for the coal processing systems implemented with medium and high speed mills.

The aim of this study is to justify a comprehensive model for energy audit and monitoring of the electric-energy efficiency of the coal processing systems in the fossil-fuel power plants.

\section{MODEL ELABORATION}

The model block diagram is shown in Figure 1. The main and supplementary evaluation indices, blocks 3 and 4 respectively, can be determined according to the generalized model and methodology for EE evaluation in electric drives [17] and the model for computer-aided investigation of the effectiveness of the complex coal processing systems [15]. A description of the indices is given in Table 1. The energy $\mathrm{W}_{\Delta \psi}$ in the corresponding formula from Table 1 can be determined through the relative moisture content of coal (coal powder) by the following dependence [15]:

$$
\mathrm{W}_{\Delta \Psi}\left(\mathrm{m}_{\mathrm{c}}, \Psi_{1}, \Psi_{2}\right)=\frac{1}{3 \cdot 6 \cdot 10^{5}} \cdot \mathrm{m}_{\mathrm{c}} \cdot\left(\Psi_{1}-\Psi_{2}\right) \cdot \mathrm{W}_{\mathrm{eva}}^{*}, \mathrm{kWh}
$$

where $\psi_{1}$ и $\psi_{2}$ are the relative moisture contents of the raw coal prior to the mill and of the coal powder after it, respectively, \%; $\mathrm{m}_{\mathrm{c}}$ - the mass of the processed coal, $\mathrm{kg} ; \mathrm{W}^{*}{ }_{\mathrm{eva}}$ - the specific heat of evaporation of the moisture in coal, $\mathrm{kJ} / \mathrm{kg}$.

In case that the coal processing system is implemented without intermediate powder hopper, the mills are few in number and are characterized by an operation in parallel. The case of simultaneous supply of one or more intermediate powder hoppers by several parallel operating pulverizes (ball mills) is also possible. For such conditions, it is feasible the target model [17] for EE evaluation of grouped drives (Block 6) to be applied. The interdependence between power consumed and the relative consumption, as well as the disregarding the available capacity usability can be considered as disadvantages of this development leading to insufficient informativeness. Here, these disadvantages are eliminated by interpretation of the model taking into account the nominal power capacity of the available drives. Thus, the following expressions to determine the aggregate relative power consumption $\mathrm{E}^{*}$ agg of the coal processing systems can be written:

- coal processing system with intermediate powder hopper:

$$
\begin{gathered}
\mathrm{E}_{\mathrm{agg}}^{*}=\frac{1}{2}\left(\frac{\mathrm{E}_{11}^{*} \mathrm{P}_{\mathrm{n} 11}+\mathrm{E}_{12}^{*} \mathrm{P}_{\mathrm{n} 12}+\ldots+\mathrm{E}_{1 \mathrm{i}}^{*} \mathrm{P}_{\mathrm{n} 1 \mathrm{i}}+\ldots+\mathrm{E}_{1 \mathrm{~m} 1}^{*} \mathrm{P}_{\mathrm{n} 1 \mathrm{~m}_{1}}}{\mathrm{P}_{\mathrm{n} 11}+\mathrm{P}_{\mathrm{n} 12}+\ldots+\mathrm{P}_{\mathrm{n} 1 \mathrm{i}}+\ldots+\mathrm{P}_{\mathrm{n} 1 \mathrm{~m}_{1}}}+\right. \\
\left.+\frac{\mathrm{E}_{21}^{*} \mathrm{P}_{\mathrm{n} 21}+\mathrm{E}_{22}^{*} \mathrm{P}_{\mathrm{n} 22}+\ldots+\mathrm{E}_{2 \mathrm{i}}^{*} \mathrm{P}_{\mathrm{n} 2 \mathrm{i}}+\ldots+\mathrm{E}_{2 \mathrm{~m}_{2}}^{*} \mathrm{P}_{\mathrm{n} 2 \mathrm{~m}_{2}}}{\mathrm{P}_{\mathrm{n} 21}+\mathrm{P}_{\mathrm{n} 22}+\ldots+\mathrm{P}_{\mathrm{n} 2 \mathrm{i}}+\ldots+\mathrm{P}_{\mathrm{n} 2 \mathrm{~m}_{2}}}\right) \Rightarrow \mathrm{MIN}
\end{gathered}
$$

- coal processing system without intermediate powder hopper: 


$$
\mathrm{E}_{\mathrm{agg}}^{*}=\frac{\mathrm{E}^{*}{ }_{11} \cdot \mathrm{P}_{\mathrm{n} 11}+\mathrm{E}^{*}{ }_{12 \cdot} \cdot \mathrm{P}_{\mathrm{n} 12}+\ldots+\mathrm{E}^{*}{ }_{1 \mathrm{i}} \cdot \mathrm{P}_{\mathrm{n} 1 \mathrm{i}}+\ldots \mathrm{E}^{*}{ }_{1 \mathrm{~m}} \cdot \mathrm{P}_{\mathrm{n} 1 \mathrm{~m}_{1}}}{\mathrm{P}_{\mathrm{n} 11}+\mathrm{P}_{\mathrm{n} 12}+\ldots+\mathrm{P}_{\mathrm{n} 1 \mathrm{i}}+\ldots \mathrm{P}_{\mathrm{n} 1 \mathrm{~m}_{1}}} \Rightarrow \mathrm{MIN}
$$

where $E^{*}{ }_{11}, E^{*}{ }_{12}+\ldots+E^{*}{ }_{1 i}+\ldots+E^{*}{ }_{1 m 1}$ are the relative consumptions of the mills (low-, medium- and high-speed mills) of the coal processing system; $\mathrm{P}{ }_{n 11}, \mathrm{P} *_{n 12}+\ldots+\mathrm{P} *_{n 1 i}+\ldots+\mathrm{P}{ }_{n 1 \mathrm{~m} 1}$ are the nominal powers of the mill'

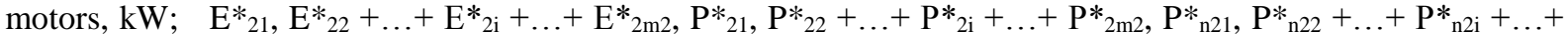
$\mathrm{P}^{*}{ }_{\mathrm{n} 2 \mathrm{~m} 2}$ are the same quantities but for the mill fans; $\mathrm{m}_{1}$ and $\mathrm{m}_{2}$ are the numbers of the mills and mill fans, respectively.

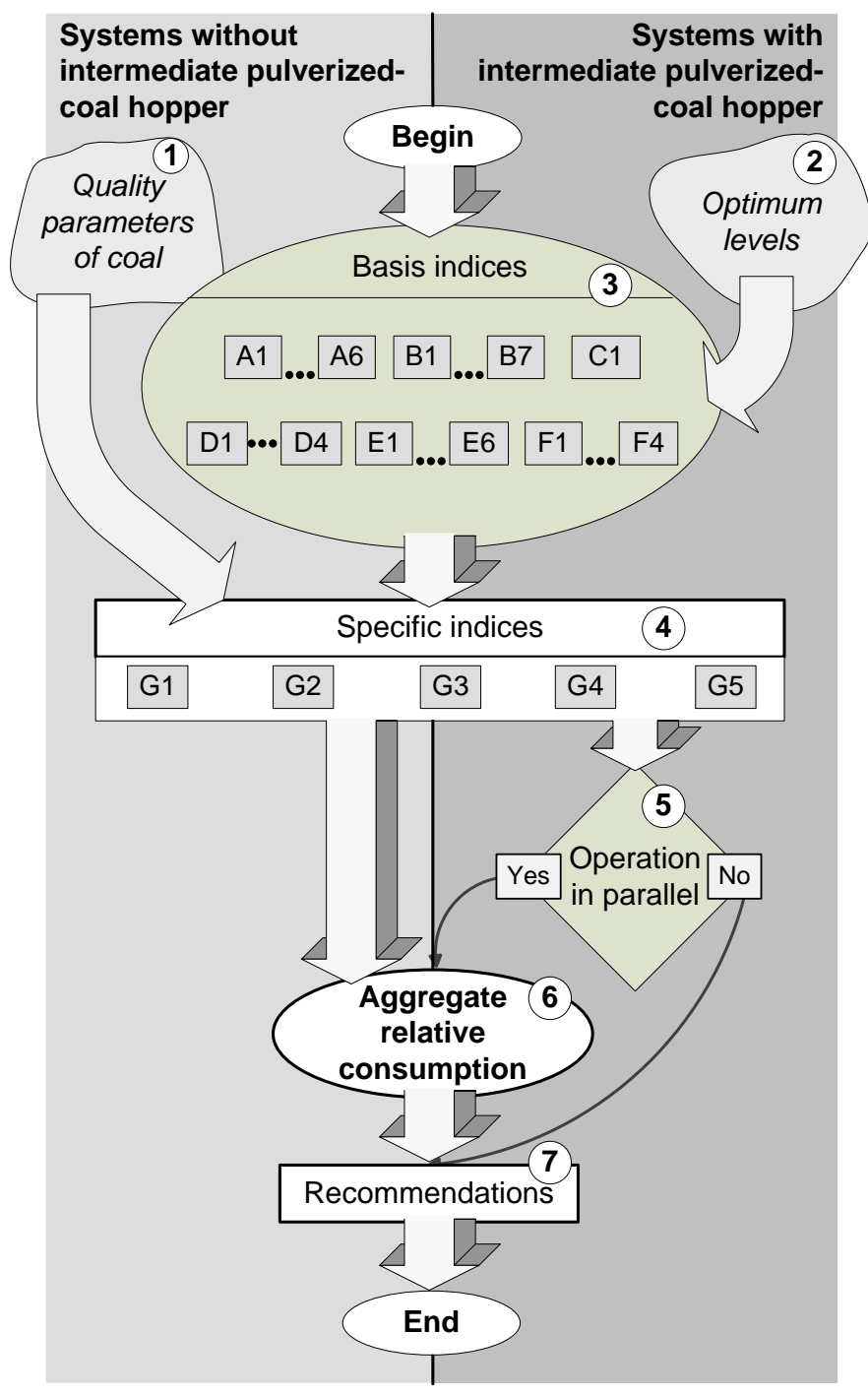

Fig. 1. Block diagram of a model for energy audit and monitoring of the coal processing systems in the fossilfuel power plants.

The dependences (2) and (3) allow not only an evaluation of the losses due to low load levels and structural imperfections, but also EE optimization by replacing oversized motors.

The necessary input information of the developed model (blocks 1 and 2, Figure 1) includes data on the quality parameters of the fuel used and on the optimal active and reactive power levels that can be fixed by applying the graphically-analytical model for the determination of the energy-efficient modes of operation of the mill-driving electric motors [17]. 
Table 1. Indices for energy-efficiency audit and monitoring of the coal processing systems in fossil-fuel power plants $[15,17]$.

\begin{tabular}{|c|c|c|c|c|}
\hline $\begin{array}{l}\stackrel{0}{0} \\
\stackrel{0}{0}\end{array}$ & 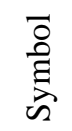 & $\stackrel{\mathscr{\varrho}}{\leftrightarrows}$ & Description & Determination \\
\hline \multirow{6}{*}{$\begin{array}{l}\ll \\
ٍ \\
0 \\
0\end{array}$} & $\mathrm{~A}_{1}$ & $\mathrm{~kW}$ & $\begin{array}{l}\text { Active power in the optimum operation of } \\
\text { the coal pulveriser/mill fan }\end{array}$ & \multirow{2}{*}{ By using the model in [17] } \\
\hline & $\mathrm{A}_{2}$ & $\mathrm{kVAr}$ & $\begin{array}{l}\text { Reactive power in the optimum operation of } \\
\text { the coal pulveriser/mill fan }\end{array}$ & \\
\hline & $\mathrm{A}_{3}$ & $\mathrm{~h}$ & Optimum operating time & $A_{3}=\frac{B_{4}}{A_{1}-C_{1}}$ \\
\hline & $\mathrm{A}_{4}$ & $\mathrm{kWh}$ & $\begin{array}{l}\text { Non-useful electric power consumption in } \\
\text { optimum operation }\end{array}$ & $A_{4}=C_{1} \cdot A_{3}$ \\
\hline & $\mathrm{A}_{5}$ & $\mathrm{kWh}$ & $\begin{array}{l}\text { Total electric power consumption in } \\
\text { optimum operation }\end{array}$ & $A_{5}=A_{1} \cdot A_{3}$ \\
\hline & $\mathrm{A}_{6}$ & - & $\begin{array}{l}\text { Relative electric power consumption in } \\
\text { optimum operation }\end{array}$ & $A_{6}=1+\frac{C_{1}}{A_{1}-C_{1}}$ \\
\hline \multirow{7}{*}{ ڤ్ } & $\mathrm{B}_{1}$ & $\mathrm{~kW}$ & Average active power in actual operation & $B_{1}=\frac{1}{n} \cdot \sum_{i=1}^{i=n} P_{a c t, i}$ \\
\hline & $\mathrm{B}_{2}$ & $\mathrm{kVAr}$ & Average reactive power in actual operation & $B_{2}=\frac{1}{n} \cdot \sum_{i=1}^{i=n} Q_{a c t, i}$ \\
\hline & $\mathrm{B}_{3}$ & $\mathrm{~h}$ & Actual operating time & $B_{3}=n . \delta$ \\
\hline & $\mathrm{B}_{4}$ & $\mathrm{kWh}$ & Useful electric power consumption & $B_{4}=\left(B_{1}-C_{1}\right) \cdot B_{3}$ \\
\hline & $\mathrm{B}_{5}$ & $\mathrm{kWh}$ & $\begin{array}{l}\text { Non-useful electric power consumption in } \\
\text { actual operation }\end{array}$ & $B_{5}=C_{1} \cdot B_{3}$ \\
\hline & $\mathrm{B}_{6}$ & $\mathrm{kWh}$ & $\begin{array}{l}\text { Total electric power consumption in actual } \\
\text { operation }\end{array}$ & $B_{6}=B_{4}+B_{5}$ \\
\hline & $\mathrm{B}_{7}$ & - & $\begin{array}{l}\text { Relative electric power consumption in } \\
\text { actual operation }\end{array}$ & $B_{7}=1+\frac{C_{1}}{B_{1}-C_{1}}$ \\
\hline $\begin{array}{l}0 \\
0 \\
0 \\
0 \\
0\end{array}$ & $\mathrm{C}_{1}$ & $\mathrm{~kW}$ & Active power in no-load operation & By measurement \\
\hline \multirow{4}{*}{ 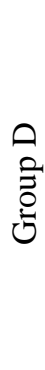 } & $\mathrm{D}_{1}$ & - & $\begin{array}{l}\text { Coefficient of overrun of total energy } \\
\text { consumed }\end{array}$ & $D_{1}=\frac{B_{6}}{A_{5}}$ \\
\hline & $\mathrm{D}_{2}$ & - & $\begin{array}{l}\text { Coefficient of overrun of non-useful energy } \\
\text { consumed }\end{array}$ & $D_{2}=\frac{B_{5}}{A_{4}}$ \\
\hline & $\mathrm{D}_{3}$ & $\mathrm{~h}$ & Overrun of operating time & $D_{3}=B_{3}-A_{3}$ \\
\hline & $\mathrm{D}_{4}$ & $\mathrm{kWh}$ & Overrun of electric energy & $D_{4}=B_{6}-A_{5}$ \\
\hline \multirow{2}{*}{ 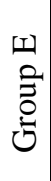 } & $\mathrm{E}_{1}$ & $\%$ & $\begin{array}{l}\text { Deviation from the maximum electric motor } \\
\text { efficiency in optimum operation }\end{array}$ & $\mathrm{E}_{1}=\eta_{\max }-\eta_{\mathrm{op}}$ \\
\hline & $\mathrm{E}_{2}$ & $\%$ & $\begin{array}{l}\text { Deviation from the maximum electric motor } \\
\text { efficiency in actual operation }\end{array}$ & $\mathrm{E}_{2}=\eta_{\max }-\eta_{\text {act }}$ \\
\hline
\end{tabular}




\begin{tabular}{|c|c|c|c|c|}
\hline & $\mathrm{E}_{3}$ & $\%$ & Maximum electric motor efficiency & $\begin{array}{l}\text { On the basis of data from } \\
\text { catalogues or other technical } \\
\text { literature }\end{array}$ \\
\hline & $\mathrm{E}_{4}$ & - & $\begin{array}{l}\text { Deviation of the power factor from the } \\
\text { desired value in optimum operation }\end{array}$ & $\mathrm{E}_{4}=\mathrm{E}_{6}-\frac{\mathrm{A}_{1}}{\sqrt{\mathrm{A}_{1}^{2}+\mathrm{A}_{2}^{2}}}$ \\
\hline & $\mathrm{E}_{5}$ & - & $\begin{array}{l}\text { Deviation of the power factor from the } \\
\text { desired value in actual operation }\end{array}$ & $\mathrm{E}_{5}=\mathrm{E}_{6}-\frac{\mathrm{B}_{1}}{\sqrt{\mathrm{B}_{1}^{2}+\mathrm{B}_{2}^{2}}}$ \\
\hline & $\mathrm{E}_{6}$ & - & Desired power factor & A set (input) value \\
\hline & $\mathrm{F}_{1}$ & $\mathrm{~kW}$ & $\begin{array}{l}\text { Standard deviation of the active power in } \\
\text { actual operation }\end{array}$ & $\mathrm{F}_{1}=\sqrt{\frac{1}{(\mathrm{n}-1)} \cdot \sum_{\mathrm{i}=1}^{\mathrm{i}=\mathrm{n}}\left(\mathrm{P}_{\mathrm{i}}-\mathrm{B}_{1}\right)^{2}}$ \\
\hline $\begin{array}{ll}1 \\
2 \\
=\end{array}$ & $\mathrm{F}_{2}$ & - & $\begin{array}{l}\text { Coefficient of variation of the active power } \\
\text { in actual operation }\end{array}$ & $\mathrm{F}_{2}=\frac{\mathrm{F}_{1}}{\mathrm{~B}_{1}}$ \\
\hline ن் & $\mathrm{F}_{3}$ & $\mathrm{kVAr}$ & $\begin{array}{l}\text { Standard deviation of the reactive power in } \\
\text { actual operation }\end{array}$ & $\mathrm{F}_{3}=\sqrt{\frac{1}{(\mathrm{n}-1)} \cdot \sum_{\mathrm{i}=1}^{\mathrm{i}=\mathrm{n}}\left(\mathrm{Q}_{\mathrm{i}}-\mathrm{B}_{2}\right)^{2}}$ \\
\hline & $\mathrm{F}_{4}$ & - & $\begin{array}{l}\text { Coefficient of variation of the reactive power } \\
\text { in actual operation }\end{array}$ & $\mathrm{F}_{4}=\frac{\mathrm{F}_{3}}{\mathrm{~B}_{2}}$ \\
\hline & $\mathrm{G}_{1}$ & $\mathrm{kWh} / \mathrm{t}$ & $\begin{array}{l}\text { Specific electric energy consumption for } \\
\text { processing (moisture evaporation, milling) of } \\
\text { a unit of mass of coal }\end{array}$ & $G_{1}=\frac{B_{6}}{m_{c}} \cdot 10^{3}=G_{2}+G_{3}$ \\
\hline & $\mathrm{G}_{2}$ & $\mathrm{kWh} / \mathrm{t}$ & $\begin{array}{l}\text { Specific electric energy consumption for } \\
\text { processing of the useful mass of coal }\end{array}$ & $G_{2}=10^{-2}\left(100-\varepsilon+\psi_{1}\right) \cdot G_{1}$ \\
\hline 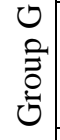 & $\mathrm{G}_{3}$ & $\mathrm{kWh} / \mathrm{t}$ & $\begin{array}{l}\text { Specific electric energy consumption for } \\
\text { processing of the ballast (the non-useful } \\
\text { mass) of coal }\end{array}$ & $G_{3}=10^{-2} \cdot\left(\varepsilon+\psi_{1}\right) \cdot G_{1}$ \\
\hline & $\mathrm{G}_{4}$ & $\mathrm{kWh} / \mathrm{MWh}$ & $\begin{array}{l}\text { Specific electric energy consumption towards } \\
\text { the heat of combustion of coal }\end{array}$ & $\mathrm{G}_{4}=\frac{3 \cdot 6 \cdot 10^{6}}{\mathrm{Q}_{\mathrm{L}}} \cdot \frac{\mathrm{W}_{\mathrm{el} . \mathrm{p}}+\mathrm{W}_{\Delta \Psi}}{\mathrm{m}_{\mathrm{c}}}$ \\
\hline & $\mathrm{G}_{5}$ & - & $\begin{array}{l}\text { Coefficient of deviation of the coal ballast } \\
\text { from practically minimum ballast }\end{array}$ & $G_{5}=\frac{\varepsilon+\psi_{1}}{\varepsilon_{\min }+\psi_{1 . \min }}$ \\
\hline & $\begin{array}{l}\mathrm{i}-\mathrm{t} \\
\text { asur } \\
\text { he } \mathrm{r} \\
\text { the }\end{array}$ & $\begin{array}{l}\text { asured valu } \\
\text { nts in hours; } \\
\text { lum and actu } \\
\text { eriser (pulve } \\
\text { or evaporati } \\
\text { actual ash }\end{array}$ & $\begin{array}{l}\text { Imber of the measurements in averaging the a } \\
\text { the } \mathrm{i} \text {-th measured value of the active power of } \\
\text { of the reactive power in } \mathrm{kVAr} ; \delta-\text { the tin } \\
\text { max - the maximum electric motor efficiency in } \\
\text { operation in } \% \text {; } \mathrm{Q}_{\mathrm{L}} \text { - lower heating value, } \mathrm{kJ} / \mathrm{k} \\
\text { er and mill fan) for milling and transportation o } \\
\text { of a part of the moisture in the coal that incon } \\
\text { ntent and the minimum contents of ash and }\end{array}$ & $\begin{array}{l}\text { tive and reactive powers of the coal } \\
\text { the pulveriser/mill fan in } \mathrm{kW} \text {; } \mathrm{Q}_{\text {act,i }}- \\
\mathrm{e} \text { interval between two consecutive } \\
\% ; \eta_{\text {op }} \text { and } \eta_{\text {act }}-\text { the motor efficiency } \\
; \mathrm{W}_{\text {el.p }}-\text { the electric energy consumed } \\
\text { coal, } \mathrm{kWh} ; \mathrm{W}_{\Delta \psi}-\text { the thermal energy } \\
\text { es in the pulveriser, } \mathrm{kWh} ; \varepsilon, \varepsilon_{\min } \text { and } \\
\text { oisture in coal, respectively, } \% \text { (the } \\
\text { ristics of the used coal). }\end{array}$ \\
\hline
\end{tabular}

\section{OBJECT OF AUDIT}

A coal processing system of a steam generator type Еп-670-140 in a fossil-fuel power plant is singled out as a research object. At the time of the audit, the quality parameters of coal have the values shown in Table 2.

The system is characteristic in technical parameters and installed capacities for most of the existing steam generators at the plant. It consists of eight identical pulverisers implemented by high-speed impact mills (HSIM) 
and arranged two to each of the four sides of the combustion chamber. At the time of the study, six of them worked at an output of $60 \mathrm{t} / \mathrm{h}$ each as two of the pulverisers were in reserve. This is the normal mode for the power unit.

Table 2. Data on the quality parameters of coal in a fossil-fuel power plant.

\begin{tabular}{|c|c|c|c|c|}
\hline \multirow{2}{*}{ Ash content } & Moisture content & Sulphur content & Xylitol content & Lower heating value \\
\hline$\%$ & $\%$ & $\%$ & $\%$ & $\mathrm{kcal} / \mathrm{kg}$ \\
\hline 17.0 & 56.8 & 2.21 & 4.50 & 1440 \\
\hline
\end{tabular}

The flow diagram of one of the composite pulverisers' systems is shown in Figure 2, and the technical characteristics of their main elements are listed in Table 3.

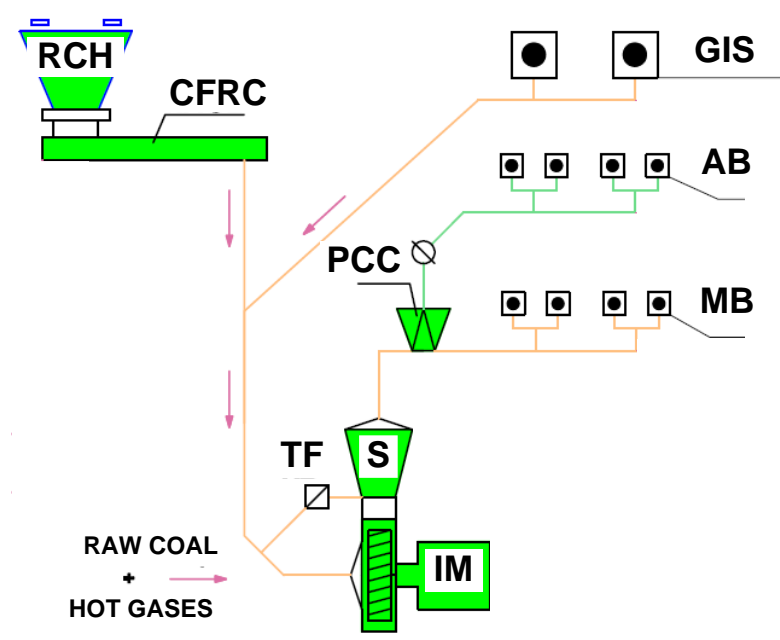

Fig. 2. Flow diagram of a pulveriser system in fossil-fuel power plant:

$\mathrm{RCH}$ - raw coal hopper; CFRC - combined feeder for raw coal; S - separator; TF - throttling flaps; PCC pulverized-coal concentrator; GIS - gas-intake shaft; AB - auxiliary burners; MB - main burners; IM - high speed impact mill.

Table 3. Technical data and parameters of a pulveriser system in a fossil-fuel power plant.

\begin{tabular}{|l|c|c|c|}
\hline \multicolumn{1}{|c|}{--} & Mill & Dispenser & Feeder \\
\hline \hline Type & MB 3300/800 & Chain & Chain \\
\hline Output, kg/s & 19.44 & $3.89-19.44$ & $3.89-19.44$ \\
\hline Type of the induction motor (IM) & AKH3-2-I6-57-I2 Y3 & AD-180M-4 & MOM-225M-8 \\
\hline Nominal power if the IM, kW & 800 & 15 & 22 \\
\hline Nominal voltage of the IM, kV & 6.3 & 0.4 & 0.4 \\
\hline Nominal current of the IM, A & 102 & 30 & 45 \\
\hline Nominal cos $\varphi$ of the IM & 0.8 & 0.87 & 0.91 \\
\hline Efficiency of the IM, $\%$ & 94.3 & 87.5 & 89.8 \\
\hline
\end{tabular}

The fuel enters the raw coal hopper $(\mathrm{RCH})$ after pre-treatment. Coal is scooped from the RCH by a raw coal dispenser (RCD), and then it enters the raw coal feeder (RCF) and turn to gas-intake shafts (GIS). Given the proportional change in the rotational speed of the RCD to RCF, these facilities are combined and considered as combined feeders for raw coal (CFRC). The humidity in coal starts to be detracted in the GIS with the aid of hot gases drawn from the upper part of the combustion chamber. The so prepared fuel enters the impact mill (IM), whereby it is ground to powder and, together with the hot gases, is directed into the combustion chamber. After $\mathrm{IM}$, the powder-gas mixture passes through the separator $(\mathrm{S})$, wherein the coarse particles are returned for regrinding in IM. After the separator, the coal powder passes through a pulverized-coal concentrator (PCC), where a distribution of the mixture between the main $(\mathrm{MB})$ and the auxiliary $(\mathrm{AB})$ burners is provided. Flaps 'airmixture', through which the powder-gas mixture is additionally distributed between $\mathrm{MB}$ and $\mathrm{AB}$, are installed prior the AB. 


\section{RESULTS}

The used measurement system for determining the electric loads is presented in section 7.2 of [17]. The mass of coal was measured using the plant's monitoring system. The obtained results are shown in Figure 3...Figure 6 and Table 4. It can be seen that the audited HSIM work in similar loads. Their electric loads are well grouped around their average values and have low levels of dispersion. The standard deviations for the active powers of the individual mills currently vary from 12.15 to $16.34 \mathrm{~kW}$, and for the reactive powers - from 9.13 to $12.25 \mathrm{kVAr}$, as the generalized standard deviation, calculated on the basis of all available data, is $14.52 \mathrm{~kW}$ for the active power and $10.89 \mathrm{kVAr}$ for the reactive, at ranges $43.6 \mathrm{~kW}$ and $33.4 \mathrm{kVAr}$ and intervals of variation $(654.7$... 698.3) $\mathrm{kW}$ and (490.4 ... 523.8) kVAr, respectively.

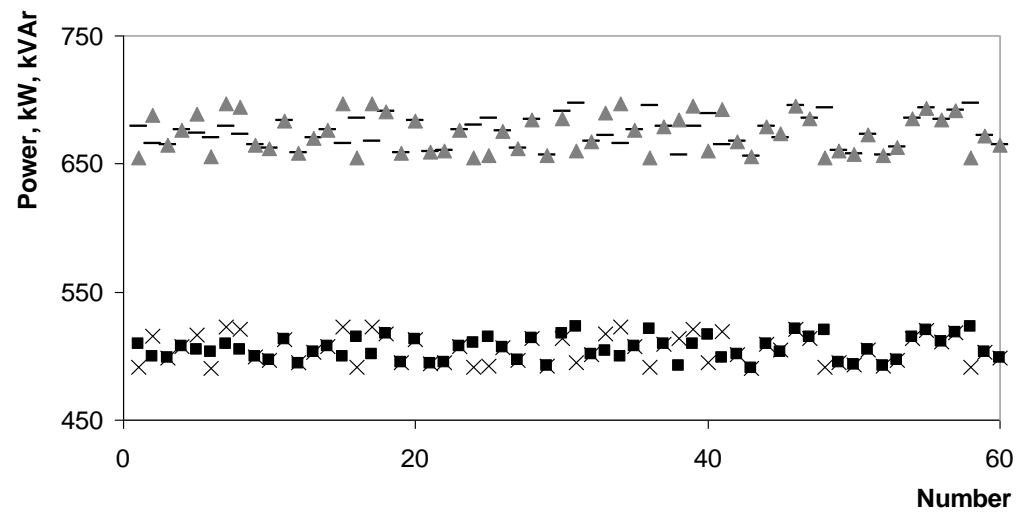

Fig. 3. Distribution of the electric loads of high-speed impact mill №1 and high-speed impact mill №2: - $\Delta$ active powers; $\boldsymbol{X} \mathbf{~ r e a c t i v e ~ p o w e r s . ~}$

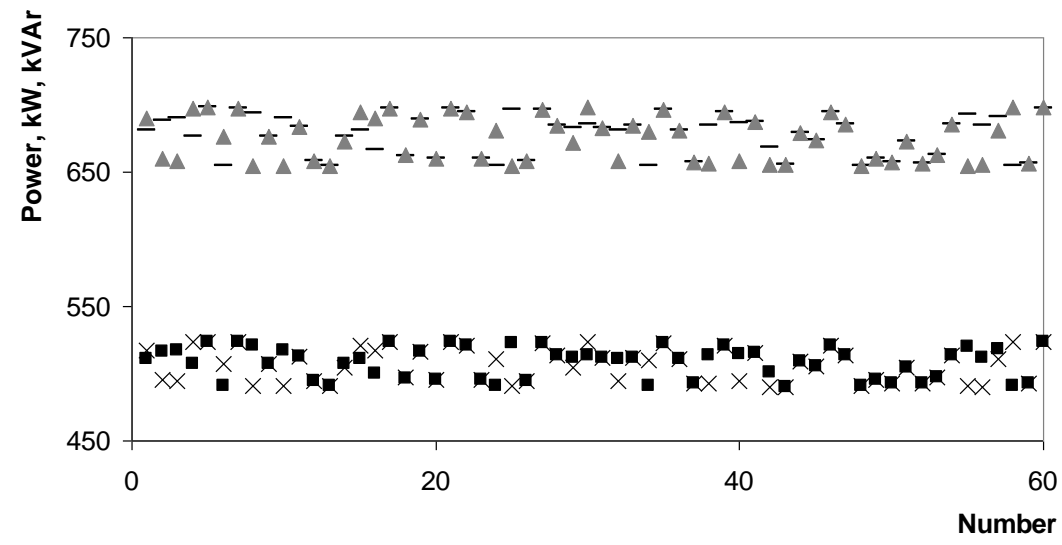

Fig. 4. Distribution of the electric loads of high-speed impact mill №3 and high-speed impact mill №4.

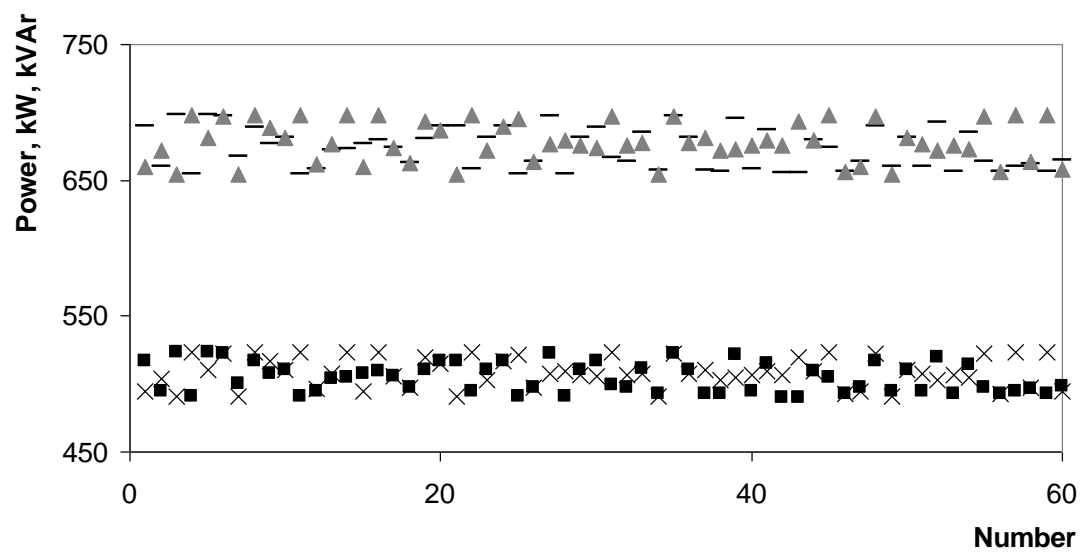

Fig. 5. Distribution of the electric loads of high-speed impact mill №5 and high-speed impact mill №6. 
Table 4. Values of the audit indices for the energy efficiency of six high-speed impact mills.

\begin{tabular}{|c|c|c|c|c|c|c|}
\hline & M1 & M2 & M3 & M4 & M5 & M6 \\
\hline $\mathrm{A}_{1}$ & 848.3 & 848.3 & 848.3 & 848.3 & 848.3 & 848.3 \\
\hline $\mathrm{A}_{2}$ & 636.2 & 636.2 & 636.2 & 636.2 & 636.2 & 636.2 \\
\hline $\mathrm{A}_{3}$ & 44.33 & 44.34 & 44.61 & 44.37 & 44.17 & 44.67 \\
\hline $\mathrm{A}_{4}$ & 134.8 & 134.7 & 135.7 & 134.9 & 134.3 & 135.8 \\
\hline$A_{5}$ & 626.6 & 626.8 & 630.7 & 627.4 & 624.5 & 631.6 \\
\hline $\mathrm{A}_{6}$ & 1.274 & 1.274 & 1.274 & 1.274 & 1.274 & 1.274 \\
\hline $\mathrm{B}_{1}$ & 674.3 & 674.4 & 677.5 & 674.9 & 672.6 & 678.2 \\
\hline $\mathrm{B}_{2}$ & 505.7 & 505.0 & 508.1 & 506.2 & 504.4 & 508.6 \\
\hline $\mathrm{B}_{3}$ & 60.00 & 60.00 & 60.00 & 60.00 & 60.00 & 60.00 \\
\hline $\mathrm{B}_{4}$ & 491.8 & 492.0 & 494.9 & 492.4 & 490.2 & 495.7 \\
\hline $\mathrm{B}_{5}$ & 182.5 & 182.3 & 182.6 & 182.4 & 182.4 & 182.5 \\
\hline $\mathrm{B}_{6}$ & 674.3 & 674.4 & 677.5 & 674.9 & 672.6 & 678.2 \\
\hline $\mathrm{B}_{7}$ & 1.371 & 1.371 & 1.369 & 1.370 & 1.372 & 1.368 \\
\hline $\mathrm{C}_{1}$ & 182.5 & 182.3 & 182.6 & 182.4 & 182.4 & 182.5 \\
\hline $\mathrm{D}_{1}$ & 1.076 & 1.076 & 1.074 & 1.076 & 1.077 & 1.074 \\
\hline $\mathrm{D}_{2}$ & 1.354 & 1.353 & 1.345 & 1.352 & 1.358 & 1.343 \\
\hline $\mathrm{D}_{3}$ & 15.67 & 15.66 & 15.38 & 15.62 & 15.82 & 15.32 \\
\hline $\mathrm{D}_{4}$ & 47.69 & 47.60 & 46.82 & 47.50 & 48.11 & 46.61 \\
\hline$E_{1}$ & 0.100 & 0.100 & 0.100 & 0.100 & 0.100 & 0.100 \\
\hline $\mathrm{E}_{2}$ & 0.500 & 0.700 & 0.500 & 0.900 & 1.100 & 0.700 \\
\hline$E_{3}$ & 94.30 & 94.30 & 94.30 & 94.30 & 94.30 & 94.30 \\
\hline $\mathrm{E}_{4}$ & 0 & 0 & 0 & 0 & 0 & 0 \\
\hline $\mathrm{E}_{5}$ & 0.070 & 0.080 & 0.060 & 0.080 & 0.090 & 0.060 \\
\hline $\mathrm{E}_{6}$ & 0.800 & 0.800 & 0.800 & 0.800 & 0.800 & 0.800 \\
\hline $\mathrm{F}_{1}$ & 1.560 & 1.896 & 1.960 & 2.128 & 1.882 & 1.901 \\
\hline $\mathrm{F}_{2}$ & 0.002 & 0.003 & 0.003 & 0.003 & 0.003 & 0.028 \\
\hline $\mathrm{F}_{3}$ & 1.170 & 1.424 & 1.460 & 1.596 & 1.407 & 1.426 \\
\hline $\mathrm{F}_{4}$ & 0.002 & 0.003 & 0.003 & 0.003 & 0.003 & 0.003 \\
\hline $\mathrm{G}_{1}$ & 11.24 & 11.24 & 11.29 & 11.25 & 11.21 & 11.30 \\
\hline $\mathrm{G}_{2}$ & 2.944 & 2.945 & 2.958 & 2.947 & 2.937 & 2.961 \\
\hline $\mathrm{G}_{3}$ & 8.294 & 8.295 & 8.333 & 8.301 & 8.273 & 8.342 \\
\hline $\mathrm{G}_{4}$ & 243.7 & 243.7 & 243.8 & 243.7 & 243.7 & 243.8 \\
\hline $\mathrm{G}_{5}$ & 1.190 & 1.190 & 1.190 & 1.190 & 1.190 & 1.190 \\
\hline
\end{tabular}

The usefully $\mathrm{B}_{4}$ and the non-usefully $\mathrm{B}_{5}$ consumed energy in actual operation moves within the intervals from 490.2 to $495.7 \mathrm{kWh}$ and from 182.3 to $182.6 \mathrm{kWh}$, accordingly, at average levels of $492.9 \mathrm{kWh}$ and $182.5 \mathrm{kWh}$. The standard deviations are $2.068 \mathrm{~kW}$ and $0.105 \mathrm{kVAr}$. The relative consumptions $\mathrm{A}_{6}$ and $\mathrm{B}_{7}$ also vary in low ranges and have average levels of 1.274 and 1.370 relative units. Low levels of variation are also characteristic of the overrun coefficients $D_{1}$ and $D_{2}$, as well as of the specific electric-power consumptions $G_{1}, G_{2}, G_{3}$ and $G_{4}$. Their mean values are 1.076 units, 1.351 units, $11.26 \mathrm{kWh} / \mathrm{t}, 2.949 \mathrm{kWh} / \mathrm{t}, 8.306 \mathrm{kWh} / \mathrm{t}$ and $243.7 \mathrm{kWh} / \mathrm{MWh}$, respectively. The average overrun of consumed energy $\mathrm{D}_{4}$ is $47.39 \mathrm{kWh}$, while the average aggregate relative electric-power consumption $\mathrm{E}^{*}{ }_{\mathrm{agg}}$ is 1.369 relative units.

\subsection{Discussion}

Based on the data presented, it is found that the actual relative consumption is close to the optimum one as the difference is about $7.5 \%$. This indicates that there are certain reserves for EE increase. The corresponding measures should be aimed primarily at improving the service conditions at the expense of potential design improvements since the coefficient $\mathrm{D}_{2}$ is $25 \%$ higher than the coefficient $\mathrm{D}_{1}$. The fuel base of the plant has 
relatively unfavourable parameters. This is established taking into account the level of the ballast coefficient $\mathrm{G}_{5}$ which is 1.06 times higher than the levels found in previous relevant studies [15].

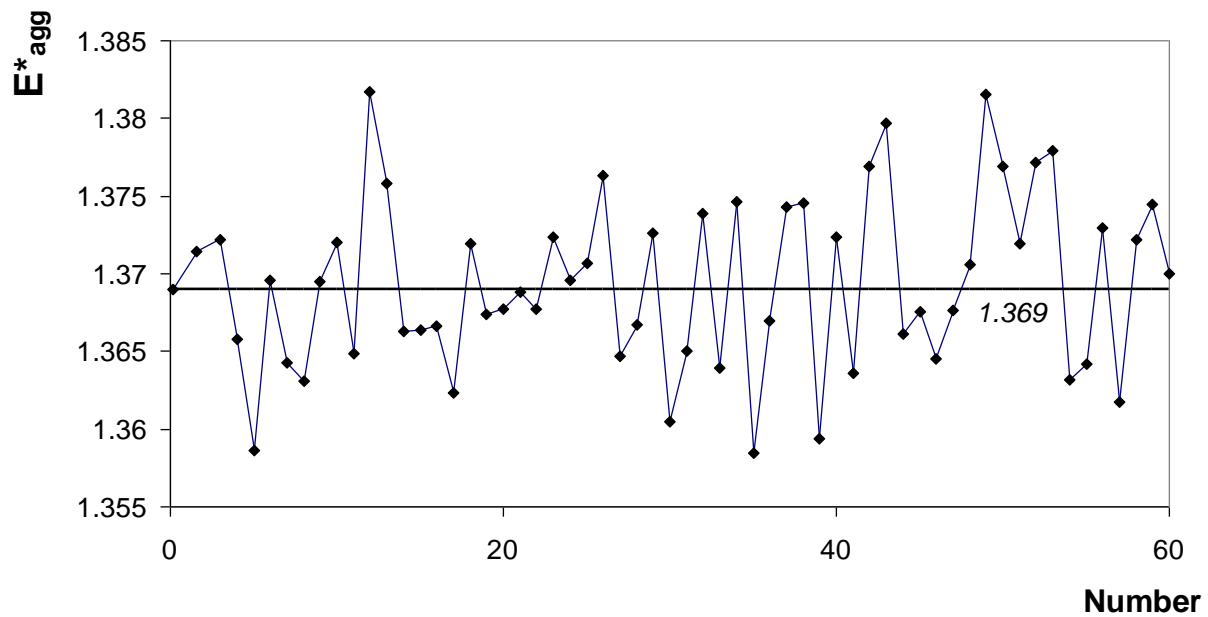

Fig. 6. Diagram of the aggregate relative consumption of a coal processing system in a fossil-fuel power plant.

The results confirm the significant benefits in energy terms of the pulveriser systems with HSIM as compared with the systems with low-speed ball mills (LSBM), for which it is found [15] that the average relative consumption is about 60 relative units. While in design and constructional respect, HSIM are efficient enough $\left(\mathrm{D}_{1} \approx 1\right)$, the same cannot be said for LSBM where $\mathrm{D}_{1}$ reaches approximately 20 units [15].

\subsection{Recommendations}

Due to the high operational capacity and usability, a recommendation can be made to increase the audited system load with approximately $10 \%$, despite the small differences between the consumptions $\mathrm{B}_{7}$ and $\mathrm{A}_{6}$. This recommendation is justified given the fact that, at an average production cost of electricity 44.35 Euro/MWh [13], the monthly overrun of energy due to non-optimum loading is approximately 204.7 MWh while the loss of money in a month reached around 9,080 Euro.

\section{CONCLUSIONS}

(1) Based on the methodology adopted, a model for energy audit in the coal processing pulveriser systems in the fossil-fuel power plants is developed. The model is generalized in nature and allows evaluation of the losses due to lack of loading and design imperfections of the electric-power consumers, as well as energy-efficiency optimization by setting optimum operating conditions and replacing oversized motors. The model can be also used for energy-efficiency control and monitoring.

(2) The development is justified by conducting systematic studies of a typical coal processing system in operation. Overall, the results indicate acceptable levels of efficiency. The relative consumption of each investigated mill fluctuates around 1.37 relative units. However, savings in the amount of about 108,625 Euro for a period of one year can be achieved in case of achievement of optimum consumers loading.

\section{REFERENCES}

[1] Abbi, Y., Ramachandran, V., Energy efficiency improvement potential for thermal power stations through energy audits, Teri Information Digest on Energy and Environment, no 2, 2008, p. 163-171.

[2] Shanmugam, K., Efficiency analysis of coal-based thermal power generation in India during post-reform era, International Journal of Global Energy Issues, no. 1, 2005, p. 15-28.

[3] Band, D., Benten, T., Stahlhut, J., Supercritical power plants offer new lease of life for header-type heaters, Power Engineering International, no. 6, 2007, p. 51-55.

[4] Venkatesh, S., Rao, K., Komaraiah, M., Ravindra, Nath, G., Regression modeling and analysis of design parameters of coal bunkers for thermal power stations, Bulk Solids Handling, no. 6, 2002, p. 426-429. 
[5] Bassetti, F., Carrea, A., Improving boiler efficiency from the bottom up, Power Engineering International, no. 7, 2009, p. 40-42.

[6] Rosen, M., Tang, R., Improving electrical generating station efficiency by varying stack-gas temperature, International Journal of Green Energy, no. 6, 2007, p. 589-600.

[7] Perez L., Perez, F., Cerezo, J., Catediano, J., Martin-Sanchez, J., Adaptive predictive control in a thermal power station, In: IEEE Conference on Control Applications - Proceedings, vol. 1, 1994, p. 747-752.

[8] Takahashi, S., Shimizu, K., Kikuchi, M., Ikematsu, T., Advanced information and control system for thermal power stations, Hitachi Review, no. 3, 1997, p. 143-146.

[9] Nedev, G., Otnosno elektropotreblenieto za sobstvenite nujdi na parogeneratorite v TEC, In: Proceedings of the University of Ruse, vol. 46, series 3.1, 2007, p. 11-15.

[10] George, N., Modernization plays vital role for coal fired power plants, Power Engineering International, vol. 19 , no. 8,2011, p. 50-55.

[11] Ol'khovskii, G., Tumanovskii, A., Rezinskikh V., Increasing the efficiency of the power station of JSC "Mosènegro", Power Technology and Engineering, no. 1, 2008, p. 32-37.

[12] Zakon za energijnata efektivnost, V sila ot 14.11.2008 g., izm. DV, br.15 ot 23 Fevruari, 2010.

[13] Dinolov, O., Mihailov, L., Zlatev, Z., Obsledvane za energijna efektivnost na ventilatorna melnica, In: Proceedings of the workshop 'Renewable energy sources in the cross-boarder region Romania - Bulgaria RESOP-DEV MIS-ETC code: 222', Ruse, 14-15 June, 2012, p. 258-260.

[14] Dinolov, O., Specifika i faktori pri ocenkata na energijnata efektivnost na sistemite za vaglepodgotovka v termichnite elektrocentrali, In: Proceedings of the University of Ruse, vol. 46, series 3.1, 2007, p. 23-27.

[15] Andonov, K., Dinolov, O., Kirchev, V., Nedev, G., Izsledvane na energijnata efektivnost na kompleksna sistema za vaglepodgotovka, Energetika, no. 5, 2008, p. 14-24.

[16] Dinolov, O., Nedev, G., Kirchev, V., Andonov, K., Izsledvane na energijnata efektivnost na prahoprigotviashta sistema s mejdinen bunker, In: Proceedings of the University of Ruse, vol. 46, series 3.1, 2007, p. 16-22.

[17] Andonov, K., Dinolov, O., Mihailov, L., Methodology for energy-efficiency investigation of electrical consumers, Journal of Engineering Studies and Research, vol. 18, no. 4, 2012, p. 6-19. 